\title{
Toxicological pathology of dab Limanda limanda along pollution gradients in the southern North Sea
}

\author{
M. G. Simpson ${ }^{1}$, T. H. Hutchinson ${ }^{2}$ \\ ${ }^{1}$ ZENECA, Central Toxicology Laboratory, Alderley Edge, Macclesfield, Cheshire SK10 4TJ, United Kingdom \\ ${ }^{2}$ ZENECA Limited, Brixham Environmental Laboratory, Freshwater Quarry, Brixham, Devon TQ5 0E6, United Kingdom
}

\begin{abstract}
During the Bremerhaven Workshop non-overtly diseased female dab Limanda limanda, 17 to $27 \mathrm{~cm}$ in length, were sampled for detailed histopathology along a $200 \mathrm{~km}$ transect (Stns 3, 5, 6, 7, 8 \& 9) extending out from the Elbe estuary region ( $\operatorname{Stn} 3$ ) to the northwestern region of the Dogger Bank ( $\operatorname{Stn} 9$ ) in the southern North Sea. During the period March 12 to 30, 1990, approximately 20 fish were examined from each of the above stations. Histopathological changes seen that were considered to be consistent with adverse exposure to xenobiotic compounds were confined to the heart, liver and kidney. In the heart, the prevalence of myocardial vacuolation, suggestive of fatty change, was significantly higher $(p<0.05)$ in fish from Stn 3 compared to fish from all other stations. In the liver, the most important lesions seen were well-developed foci of cellular alteration, high mitotic activity and high neutral lipid accumulation in livers of dab sampled from the most inshore station (Stn 3) compared to the reference station (Stn 7). Foci of cellular alteration and high neutral lipid accumulation were significantly greater $(p<0.05)$ at $\operatorname{Stn} 3$ compared to Stn 7 . In the kidney, the prevalance of proteinaceous $/ \mathrm{cel}$ Iular debris in Bowman's space of renal glomeruli was significantly greater $(p<0.01)$ in fish from $\operatorname{Stn} 3$ compared to fish from Stn 7 The high prevalence of foci of cellular alteration and high neutral lipid accumulation in hepatocytes in the liver of dab are consistent with the effects of adverse exposure to toxic xenobiotics. The other non-infectious changes seen in the liver, as well as those seen in the heart and kidney, are also consistent with xenobiotic exposure but other possible explanations are considered. The value of using detailed histopathology on small numbers of dab which appear grossly normal is clearly demonstrated.
\end{abstract}

\section{INTRODUCTION}

In Europe, investigations into fish diseases and their possible relationships with xenobiotic contaminants in the marine environment have tended to follow the protocols recommended by ICES (ICES 1989). These pathological methods of investigation, which were mainly limited to gross inspection, have revealed a variety of spatial and temporal trends in fish disease patterns in the North Sea (Bucke et al. 1984, Bucke 1988, 1991, Bucke \& Waterman 1988, Dethlefson 1988). This epidemiological type of approach can be complemented by the application of techniques which operate at the molecular, cellular and tissue level of organisation (Köhler 1989, Moore 1990, 1992a, b, Moore \& Simpson
1991, Stegeman \& Lech 1991, Varanasi \& Stein 1991, Cameron \& Berg 1992, Köhler et al. 1992, Lowe et al. 1992, Moore \& Evans 1992). The combined methodology coupled with the use of supportive laboratory bioassays should help to define causal links between some classes of contaminant and specific types of toxic injury in fish. In Europe, only a few field studies have traced links between fish disease and chemical exposure (see Köhler 1989) but in North America where xenobiotic contamination of the marine environment has been investigated more extensively, good data exists for linking hepatic neoplasms (and related lesions) with exposure to toxic chemicals in marine fish species (Mix 1986, Malins et al. 1988, Murchelano \& Wolke 1991, Myers et al. 1991, Varanasi \& Stein 1991). 
Although the common dab Limanda limanda is the species recommended for offshore sampling in European fish disease surveys, little published information appears to be available on its general pathology. The objectives of this study were (1) to obtain a basic pathology profile of the major organs and tissues of dab, in specimens (females 17 to $27 \mathrm{~cm}$ in length) that appeared to be free from grossly visible signs of disease, (2) to highlight changes seen that are consistent with previous exposure to xenobiotics and (3) to link these with changes seen in similar specimens examined by techniques of cellular pathology. The rationale underlying the approach used in this study is defined by Moore \& Simpson (1992) and by Moore (1992b). Preliminary data, obtained from this study and relating only to the liver, has been reported by Simpson (1992).

\section{MATERIALS AND METHODS}

Dab were collected using standardised methods from Stns 3, 5, 6, 7, 8 \& 9. Captured fish were held in aerated tanks on board ship. At the dockside fish were allowed to settle for approximately $4 \mathrm{~h}$ before necropsy procedures began. Fish were killed by severing the spinal cord immediately posterior to the brain. The total length of each fish was recorded, as were the presence of both external and internal abnormalities. Fish with overt signs of external disease were excluded from this investigation. Fish were numbered individually and fixed in large containers of $10 \%$ neutral formalin.

The following organs and tissues were submitted for histological processing and histopathological examination: skin, fins, myotomes, bone, cartilage, nares, eyes (including choroid gland), brain, spinal cord, notochord, dorsal root ganglia, peripheral nerve, pituitary gland, thyroid gland, oesophagus, stomach, anterior and posterior intestine, pyloric caeca, liver, pancreas, anterior and posterior kidney, gills, pseudobranch, heart and gonad. Portions of liver were stored in fresh formalin fixative for subsequent histochemical methods. Each tissue sample was trimmed in a standardised way, dehydrated through graded ethanols, cleared in toluene and embedded in paraplast wax at 58 to $60^{\circ} \mathrm{C}$. Transverse sections were cut and stained routinely with alum haematoxylin and eosin. Histochemical techniques were used to support histopathological diagnosis. These included periodic acid-Schiff (PAS) with/without diastase for glycogen and neutral mucosubstances, Alcian blue 2.5 for polyanionic groups, Lillie and Ashburn's Oil Red $O$ for neutral lipid, Bromphenol blue for basic protein groups and various general triple staining techniques (Pearse 1968, 1970).
Diagnostic data was entered into a computerised pathology system (ARTEMIS). Fisher's Exact Test was used to compare diagnostic data from the sites, using Stn 7 as the reference site against which all other sites were compared.

\section{RESULTS}

The complete spectrum of pathological changes recorded will be given elsewhere. Changes recorded and discussed here are those mostly considered to be relevant to contaminant impact. No microscopic neoplastic changes were seen, nor were there any major pathological findings seen in the nervous system, endocrine system and reproductive organs. No histopathological evidence of bacterial and fungal infections was seen. Histopathological evidence of viral infection was confined to lymphocystis disease in skin and occasionally kidney and spleen of dab from Stns $8 \& 9$. Over $26 \%$ of dab from Stn 9 contained skin foci of mature lymphocystis cells with distinct capsules (this prevalence was significantly greater $(p<0.05)$ compared to dab from Stn 7 ).

Infection by various parasitic agents was seen at all sites along the transect. Parasitisation by helminths was most prevalent (over $52 \%$ ) in the anterior intestine of dab from Stn 9 but this was not statistically significant when compared to those recorded in the gut of dab from Stn 7 (35\%). Protozoan infection in the anterior intestine of dab from Stn $3(25 \%)$ was significantly different $(p<0.05$ ) than that seen in the gut of dab from Stn $7(5.6 \%)$. On balance, parasitic infection tended to be most prevalent at Stns $3 \& 9$ and evoked a negligible host tissue response.

Findings considered to be of known or possible toxicological significance were restricted to the heart, liver and kidney. In the heart, the prevalance of changes in the myocardial wall consistent with lipid deposits was significantly higher in dab from $\operatorname{Stn} 3(31.6 \%)$ compared to that in the heart of the dab from $\operatorname{Stn} 7(0 \%)$. This type of myocardial vacuolation was present in just over $4 \%$ of dab from Stn 9 .

A variety of changes were seen in the liver and these are summarised in Table 1. Dab liver samples from Stns 3 \& 9 had a greater degree of hepatocellular cytoplasmic vacuolation compared to other stations (Table 1). The prevalance of this hepatocyte cytoplasmic vacuolation was significantly greater at Stn 3 compared to that seen at $\operatorname{Stn} 7(\mathrm{p}<0.05)$.

In parafin sections, hepatocellular cytoplasmic vacuolation, which presents as irregular shaped vacuoles, crissed-crossed by strands of cytoplasm, is characteristic of glycogen, e.g in the glycogen secreting livers of salmonids and in male dab livers (Simpson 
Table 1. Limanda limanda. Summary of histopathological findings in the liver of non-overtly diseased dab $(17 \mathrm{fo} 27 \mathrm{~cm})$

\begin{tabular}{|c|c|c|c|c|c|c|}
\hline Microscopic findings & $\operatorname{stn} 3$ & $\operatorname{Stn} 5$ & $\operatorname{Stn} 6$ & $\operatorname{Stn} 7$ & $\operatorname{Stn} 8$ & $\operatorname{Stn} 9$ \\
\hline No. livers examined & 20 & 20 & 20 & 19 & 18 & 23 \\
\hline \multicolumn{7}{|l|}{ No. with: } \\
\hline $\begin{array}{l}\text { Hepatocellular cytoplasmic } \\
\text { vacuolation (glycogen and lipid) }\end{array}$ & $17^{\circ}$ & 10 & 10 & 8 & 10 & 17 \\
\hline Subcapsular sinusoidal dilatation & 1 & 0 & 0 & 1 & 1 & 0 \\
\hline Scattered basophilic hepatocytes & 3 & 1 & 1 & 1 & 0 & 0 \\
\hline Apoptosis & 1 & 0 & 4 & 0 & 2 & 3 \\
\hline Haemorrhagic foci & 1 & 0 & 0 & 0 & 0 & 0 \\
\hline $\begin{array}{l}\text { Proliferation of melanomacrophage } \\
\text { centres }\end{array}$ & 2 & 2 & 0 & 0 & 1 & 0 \\
\hline Hepatocyte necrosis & 3 & 1 & 0 & 0 & 0 & 0 \\
\hline Increased mitotic activity & 4 & 1 & 0 & 0 & 0 & 0 \\
\hline $\begin{array}{l}\text { Infiltration/fibrosis of } \\
\text { melanomacrophage centres }\end{array}$ & 0 & 0 & 0 & 0 & 1 & 0 \\
\hline Foci of cellular alteration & $7^{\circ}$ & 3 & 2 & 0 & 2 & 4 \\
\hline Parasitic infection & 0 & 1 & 1 & 0 & 0 & 5 \\
\hline
\end{tabular}

unpubl. obs.). PAS reactive material labile to prior treatment with amylase is indicative of glycogen. PAS staining of the livers of paraffin sections was generally minimal, though the irregular appearance of some of the vacuoles clearly indicated that glycogen had been present in life. This was consistent with the fact that glycogen is not particularly well retained in routine formalin fixed sections. In addition to vacuoles of glycogen type, sharp edged, regular shaped vacuoles were also seen in paraffin sections of dab liver sampled along the transect. These were considered to be consistent with neutral lipid. About $55 \%$ of the dab from Stn 3 featured this hepatocellular cytoplasmic vacuolation of lipid type compared to almost $19 \%$ in the liver of dab from Stn 7 (Fig. 1). This difference was significant $(p<0.05)$. That the vacuolation was consistent with neutral lipid was confirmed as such by Oil Red $\mathrm{O}$ staining of representative cryostat sections. Hepatocyte cytoplasmic vacuolation characteristic of 'hydropic change' was not seen.

A major finding of toxicological importance was the presence in the liver of foci of cellular alteration (altered cell foci). These phenotypically distinct lesions (Fig. 2) were classified according to the standardised criteria of Harada et al. (1989) and were most prevalent at Stn 3 (Table 1), especially altered cell foci of the basophilic type. The prevalence of altered cell foci was significantly greater at $\operatorname{Stn} 3(p<0.05)$ compared to dab from $\operatorname{Stn} 7$ (Fig. 2). Other changes in the liver consisted of hepatocellular necrosis and prominent mitotic activity of hepatocytes only in dab from Stns 3 \& 5 (Table 1). Morphological markers for programmed cell death (apoptotic bodies) were also seen in dab liver but the prevalence was lowest in livers from Stns 3, 5 \& 7 (Table 1).

In the kidney, there was no evidence of significant tubular degeneration or repair in dab anywhere along the transect stations sampled (Table 2), but there was a

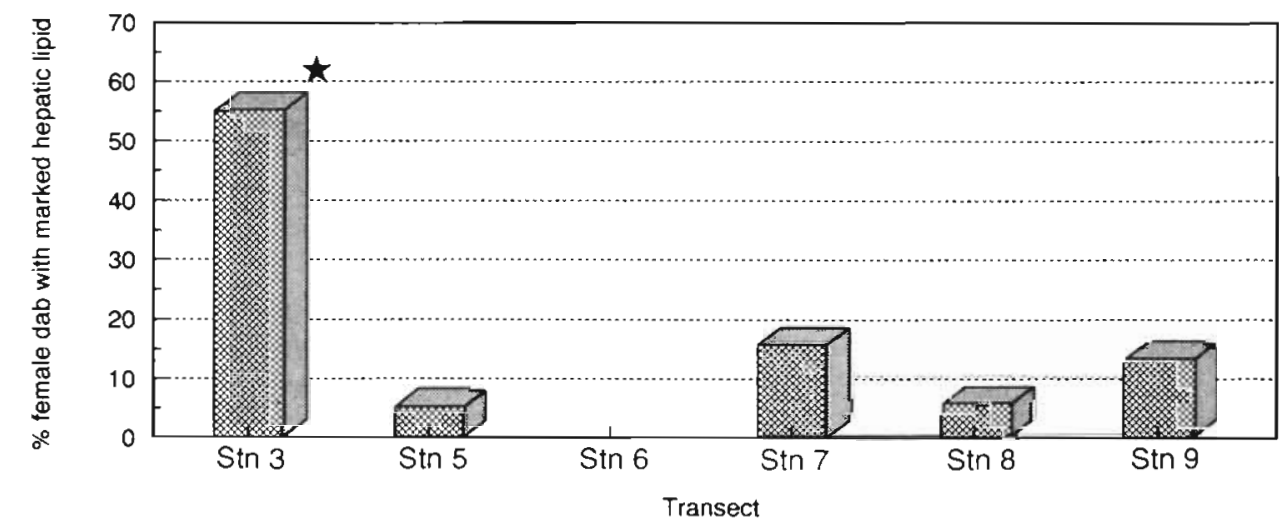

Fig. 1. Limanda limanda. Marked hepatocellular lipid vacuolation in non-overtly diseased dab $(17$ to $27 \mathrm{~cm})$. ' Significantly higher than the prevalence at Stn 7 by Fisher's Exact Test $(p<0.05)$. Vacuolation confirmed as neutral lipid by staining of representative sections with Lillie and Ashburn's Oil Red O 
Table 2. Limanda limanda. Summary of histopathological changes in the posterior kidney of non overtly diseased dab (17 to $27 \mathrm{~cm})$

\begin{tabular}{|c|c|c|c|c|c|c|}
\hline $\begin{array}{l}\text { Microscopic findings } \\
\text { No. fish examined: }\end{array}$ & $\begin{array}{c}\text { Stn } 3 \\
20\end{array}$ & $\begin{array}{c}\text { Stn } 5 \\
20\end{array}$ & $\begin{array}{c}\operatorname{Stn} 6 \\
20\end{array}$ & $\begin{array}{l}\operatorname{Stn} 7 \\
19\end{array}$ & $\begin{array}{c}\operatorname{Stn} 8 \\
18\end{array}$ & $\begin{array}{c}\operatorname{Stn} 9 \\
23\end{array}$ \\
\hline \multicolumn{7}{|l|}{ No. with: } \\
\hline $\begin{array}{l}\text { Cellular debris/proteinaceous } \\
\text { deposits in Bowman's space }\end{array}$ & $11^{\cdots}$ & 0 & 0 & 0 & 0 & 3 \\
\hline Glomerular fibrosis & 1 & 0 & 0 & 0 & 0 & 0 \\
\hline Tubular fragments in ureter lumen & 2 & 0 & 0 & 0 & 0 & 1 \\
\hline Interstitial granulomata & 2 & 0 & 0 & 0 & 0 & 0 \\
\hline Lymphocystis disease & 0 & 0 & 0 & 0 & 0 & 1 \\
\hline Tubular regeneration & 1 & 0 & 0 & 0 & 0 & 0 \\
\hline Occasional necrotic tubule & 0 & 0 & 0 & 0 & 0 & 0 \\
\hline Cystic dilatation & 0 & 0 & 0 & 0 & 0 & 1 \\
\hline Interstitial protozoan infection & 0 & 1 & 0 & 0 & 0 & 0 \\
\hline Unencapsulated helminth & 0 & 0 & 2 & 0 & 0 & 0 \\
\hline Tubular vacuolation & 1 & 0 & 0 & 0 & 0 & 0 \\
\hline
\end{tabular}

significant accumulation of cellular debris/proteinaceous deposits in the Bowman's space of the renal glomeruli of dab from Stn 3 compared to those from Stn $7(p<0.01)$.

\section{DISCUSSION}

The most serious histopathological changes seen were in the liver. Foci of cellular alteration in the vertebrate liver are generally regarded as putative pre-neoplastic changes in hepatocytes. These occur spontaneously in laboratory rodents and increase in number as a function of age. Generally they do not progress to hepatic neoplasia, but do increase dramatically in young rodents exposed chronically to a wide variety of both

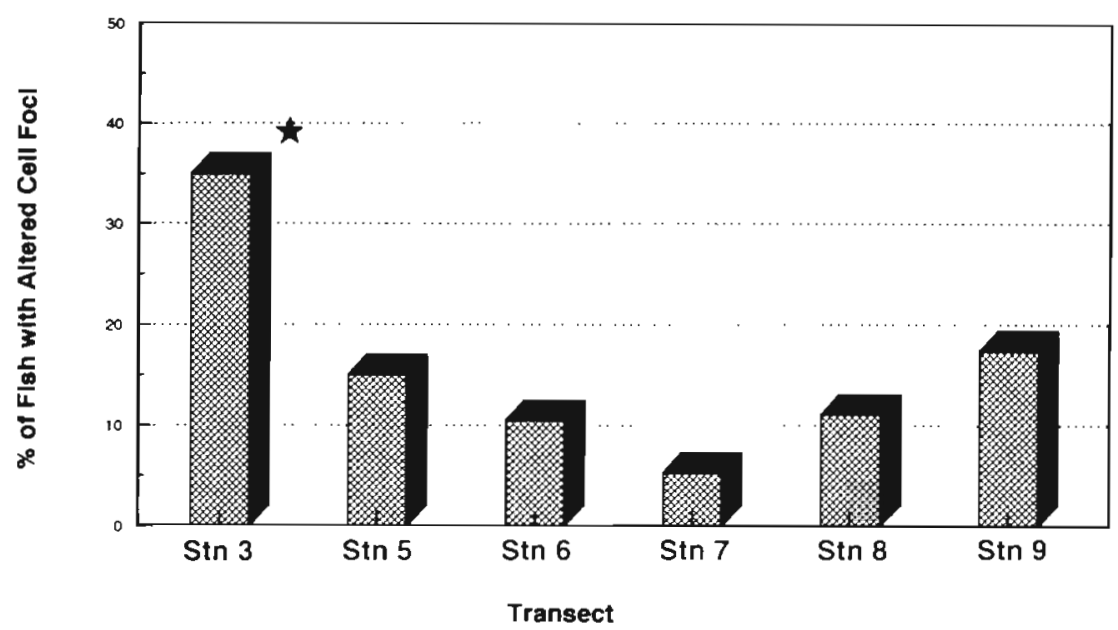

Fig. 2. Limanda limanda. Prevalence of altered cell foci in the liver of non-overtly diseased dab $(17$ to $27 \mathrm{~cm})$. - Significantly higher than the prevalence at $\operatorname{Sin} 7$ by Fisher's Exact Test ("p<0.05) genotoxic and non-genotoxic carcinogens (Bannasch et al. 1989, Harada et al. 1989). Foci of cellular alteration also occur in both laboratory-reared and wild fish (Hinton 1989, Hinton \& Lauren 1990, Myers et al. 1990. Murchelano \& Wolke 1991), can be induced by carcinogenic chemicals and contaminated sediments (Couch \& Courtney 1987, Black 1988, Hinton et al. 1988, Myers et al. 1990, Schiewe et al. 1991) and show great similarities to foci induced in the liver of laboratory rodents (Couch \& Courtney 1987). It is interesting that the prevalance of altered cell foci in the liver of dab sampled along the transect follows the trend of the contaminant levels established previously (Lohse 1990) and by Cofino et al. (1992). It has been established by Lohse (1990) that Stn 3 is the most contaminated station in terms of organochlorines, petroleum hydrocarbons and metals, decreasing out towards $\operatorname{Stn} 7$ but rising again at Stn 9. In particular, lipophilic contaminants predominate at Stn 3. Unfortunately there are no data yet available on the pathogenesis of altered cell foci in the liver of dab either from field studies or from exposure to carcinogens in the laboratory.

The limited data from published studies on non-European species of flatfish indicate that the year class prevalance of altered cell foci is first shown to be above baseline at 5 yr of age and older (Rhodes et al. 1987). In this study the age composition of dab at all stations along the transect was dominated by 4 
and 5 yr old fish (Rijnsdorp et al. 1992). Despite the dab along the transect being broadly of similar age, the prevalance rate for hepatic altered cell foci in dab from Stn 3 was significantly higher than at other sites. Conversely, the low prevalance seen in dab from Stn 7 is in keeping with similar low prevalance rates noted for dab taken from Lyme Bay, an area in the English Channel believed to be free from anthropogenic inputs (Simpson et al. unpubl. obs.). It is tempting to relate the relatively high prevalence rate of altered cell foci seen at Stn 3 to the presence of relatively high levels of lipophilic organics as established by Lohse (1990). However the situation is complicated by the recent findings of Rijnsdorp et al. (1992), where it has been shown that the dab populations over the transect are subject to some migratory movement.

It could be argued that altered hepatic cell foci could have been induced in the dab at locations other than of the transect, possibly as pelagic embryos inhabiting a xenobiotic-rich microlayer. Experimentally it has been established that pre-neoplastic and neoplastic hepatocellular changes can be induced in $0+$ class fish by a single short pulse of carcinogen, with altered foci appearing within weeks of the initial exposure and hepatocellular neoplasms within months (Hendricks et al. 1984, Black 1988, Hawkins et al. 1988). This is seen against a very low spontaneous prevalance rate. Whether older fish already showing some background levels of altered cell foci can be similary induced is not known. Nor is it known whether the residence time of dab over particular stations along the transect is sufficiently long for foci to develop. Despite these limitations it is proposed that the age-related prevalance of hepatic altered cell foci in flatfish such as the dab be further investigated as potential medium term markers of xenobiotic exposure.

Currently, it is not known whether the presence of such hepatic foci relates to particular components of the sediments at stations where the fish were collected or merely reflects xenobiotic exposure from elsewhere. Be that as it may, the relatively high prevalence of foci of cellular alteration in the liver of dab from Stn 3, coupled with prominent mitotic activity and little evidence of apoptosis, collectively suggests a toxic effect with at least a reduction in those homeostatic mechanisms that regulate normal liver growth. Whether the environmental triggers are genotoxic or epigenetic carcinogens, promoters or enhancing factors, etc., remains to be established (see Weisburger \& Williams 1991). In parallel studies to this one, Chipman et al. (1992) found no evidence of genotoxic liver damage in dab sampled along the transect. Therefore there is a possibility that the altered cell foci are being induced by a combination of factors which precipitate hepatocyte cell death (necrosis), induce cell proliferation (mitogenesis) and perhaps reduce programmed cell death (apoptosis). In the liver, necrogenic, mitogenic and apoptotic phenomena are important components in recent mechanistic approaches to experimental carcinogenesis (Cohen \& Ellwein 1990, Kraupp-Grase et al. 1990, Schulte-Herman et al. 1990).

The fact that no evidence for station-related hepatic neoplasia was seen along the transect (Vethaak 1992, Vethaak et al. 1992) is not unexpected. It is argued that whilst it is feasible for a relatively rapid onset change such as foci of cellular alteration to be related to a particular station, the neoplastic progression that will occur only in a smaller number of individuals with foci will probably be expressed after the fish have left the area, or if the cumulative dose was inadequate to result in actual neoplasia. The tagging experiments of Rijnsdorp et al. (1992) have indicated that the dab population over the sampling stations along the transect reflects a temporary aggregation of fish originating from a large area. The tumour biology of no European species of flatfish is known. Experimental data is needed on the rapid induction of early onset changes, progression versus regression, tumour latency, and mortality of tumour bearing fish in order to help better interpret findings acquired by the application of epidemiological techniques in field surveys (see Köhler 1989).

In addition to the above changes, livers of dab presented with a storage type of hepatocellular vacuolation, which appeared to follow the trend of contamination established previously (Lohse 1990), i.e. livers of dab from Stn 3 were rich in neutral lipid, those from Stn 7 showed minimal lipid, and lipid was expressed again in the livers of dab from Stn 9. In the case of lipid, the annual reproductive cycle in female dab causes a mobilisation of body reserves which are partly used for the development and ripening of the eggs which coincides with a decrease in hepatic neutral lipid as the eggs develop (Htan-Han 1978, Kamman et al. 1990). In this study, all the females examined histologically appeared to be at the same stage of spawning, and therefore would have been expected to show a similar pattern of hepatic lipid utilisation. The oocytes in dab from all along the transect were histologically similar (stages IV to VI) according to the criteria of Htan-Han (1978). Assessing the data in isolation, a differential expression of hepatocyte neutral lipid along the transect could be explained by postulating dietary differences among the fish at different sites or general nutritional status. However, looking at the data within the context of other liver changes seen, then an alternative explanation is possible. The presence of the high levels of neutral lipid in livers of dab from Stn 3 coupled with the other hepatic changes described would suggest a toxic effect, such as fatty change, rather than a physiological over-production of normal storage lipid. Over- 
all, the changes reported here are consistent with a toxic effect in the liver of dab from Stn 3 and are strengthened by the presence of lysosome impairment, reduced endocytosis, increased low density lipoprotein, increased oxyradical formation, increased endoplasmic reticulum, elevated EROD, elevated P4501A1 and the detection of ras-oncoprotein, also in livers of dab from Stn 3 (Köhler et al. 1992, Lowe et al. 1992, Moore 1992a, b, Moore \& Evans 1992, Renton \& Addison 1992). In total the data from these varied biomarkers suggest toxic liver injury in dab taken from the inshore stations. One final comment on the liver findings is that in the dab sampled there did not appear to be any evidence of hepatocellular vacuolation of the type described as hydropic change (M. J. Moore pers. comm.) and described for winter flounder, starry flounder, rock sole and white croaker from North American waters (see Moore et al. 1989, Bodammer \& Murchelano 1990, Murchelano \& Wolke 1991). The latter authors link the presence of such hydropic degeneration with exposure to xenobiotics. The apparent absence of this type of change in the dab will be the subject of further study.

Changes in the kidney were seen in dab sampled along the transect, namely proteinaceous, cellular debris in the Bowman's space of the renal glomeruli in fish from Stns $3 \& 9$. The prevalance of this renal finding was significantly greater with respect to controls only in dab from Stn 3. However, there was no significant evidence of renal tubular damage, consistent with exposure to nephrotoxic chemicals, nor was there histopathological evidence of regenerating tubules. It is possible that the proteinaceous material seen in Bowman's space represents unsalvaged protein, i.e. small molecular weight protein that normally undergoes reabsorption after passing through the renal glomeruli. This might occur if the pinocytotic activities of the renal epithelium was reduced in the kidneys of fish from Stns $3 \&$ 9. Reduced pinocytotic activity was a feature of freshly isolated hepatocytes of fish from Stn 3 (Moore 1992b).

It is concluded that this first ever study of the major organs and tissues of the dab in non-overtly diseased specimens has provided a number of leads for further investigation and has confirmed the toxicological importance of the liver in such investigations. It has highlighted the need for further studies on the presence of foci of cellular alteration. The latter have already been used as biomarkers of liver injury in field studies in the USA (Murchelano \& Wolke 1991, Myers et al. 1991). The pathology seen here represents a 'first pass' and it is possible that xenobiotic-linked changes in other organ systems may be revealed pending examination of further samples and generation of much larger data sets.

\section{LITERATURE CITED}

Bannasch, P., Enzmann, H., Klimek, F., Weber, E., Zerban, H. (1989). Significance of sequential cellular changes inside and outside foci of altered hepatocytes during hepatocarcinogenesis. Toxicol. Pathol. 4: 617-628

Bodammer, J. E., Murchelano, R. A. (1990). Cytological study of vacuolated cells and other aberrant hepatocytes in winter flounder from Boston Harbor. Cancer Res. 50: $6744-6756$

Black, J. J. (1988). Carcinogenicity tests with rainbow trout embryos: a review. Aquat. Toxicol. 11: 129-142

Bucke, D. (1988). Pathology of fish diseases in the North Sea. In: Newman, P. J., Agg, A. K. (eds.) Environmental protection of the North Sea. Heineman Professional Publishing, Oxford, p. 286-301

Bucke, D. (1991). Current approaches to the study of pollution-related diseases in fish. Bull. Eur. Ass. Fish. Pathol. 11: $46-53$

Bucke, D., Waterman, B. (1988). Effects of pollutants on fish. In: Salomans, W., Bayne, B. L., Duursma, E. K., Forstner, U. (eds.) Pollution of the North Sea - An assessment. Springer Verlag, Berlin, Heidelberg, New York, p. 612-623

Bucke, D., Waterman, B., Feist, S. (1984). Histological variations of hepato-splenic organs from the North Sea dab. Limanda limanda (L). J. Fish Dis. 7: 255-268

Cameron, P., Berg, J. (1992). Morphological and chromosomal aberrations during embryonic development in dab Limanda limanda. Mar. Ecol. Prog. Ser. 91: 163-169

Chipman, J. K., Marsh, J. W., Livingstone, D. R., Evans, B. (1992). Genetic toxicity in dab Limanda limanda from the North Sea. Mar. Ecol. Prog. Ser. 91: 121-126

Cofino, W. P., Smedes, F., de Jong, S. A., Abarnou, A., Boon, J. P., Oostingh, I., Davies, I. M., Klungsøyr, J., Wilhelmsen, S., Law, R. J., Whinnett, J A., Schmidt, D., Wilson, S (1992). The chemistry programme. Mar. Ecol. Prog. Ser. 91: $47-56$

Couch, J. A., Courtney, L. A. (1987). Hepatocarcinogenesis in estuarine fish: induced neoplasms and related lesions with comparison to mammalian lesions. J. natn. Cancer Inst. 79: $297-322$

Cohen, M., Ellwein, L. B. (1990). Cell proliferation in carcinogenesis. Science 249: $1007-1011$

Dethlesfen, V. (1988). Status report on aquatic pollution problems in Europe. Aquat. Toxicol. 11:259-286

Harada, T., Maranpot, R. R., Morris, R. W., Stitzel, K. A., Boorman, G. (1989). Morphological and stereological characterisation of hepatic foci of cellular alteration in control Fischer 344 rats. Toxicol. Pathol. 4: 579-593

Hawkins, W. E., Overstreet, R. M., Walker, W. W. (1988). Carcinogenicity tests with small fish species. Aquat. Toxicol. 11: 13-128

Hendricks, J. D., Myers, T K., Shelton, D. W. (1984). Histological progression of hepatic neoplasia in rainbow trout (Salmo gardneri). Nat. Cancer Inst. Monogr. 05: 3231-3236

Hinton, D. E. (1989). Environmental contamination and cancer in fish. Marine environ. Res. 28: 411-416

Hinton, D. E., Couch, J. A., Teh, S. J., Courtney, L. A. (1988). Cytological. changes during progression of neoplasia in selected fish species. Aquat. Toxicol. 11 77-112

Hinton, D. E., Lauren, D. J. (1990). Liver structural alterations accompanying chronic toxicity in fishes: potential biomarkers of exposure. In: Carthy, J. F., Shugut, L. K. (eds.) Biomarkers of environmental contamination. Lewis Publishers, Boca Raton, p. 17-37

Htan-Han, M. (1.978). The reproductive biology of the dab 
Limanda limanda (L) in the North Sea: seasonal changes in the ovaries. J. Fish. Biol. 13: 351-359

ICES (1986). Methodology of fish disease surveys. In: Dethlefsen, V., Egidias, E., McVicar, A. H. (eds.) Cooperative research report no. 140. ICES, Copenhagen

Kammann, U., Knickmeyer, R., Steinhart, H. (1990). Distribution of polychlorobiphenyls and Hexachlorobenzene in different tissues of the dab (Limanda limanda) in relation to lipid polarity. Bull. environ. Contam. Toxicol. 45: $552-579$

Köhler, A. (1989). Cellular effects of environmental contamination in fish from the River Elbe and the North Sea. Mar. environ. Res. 28: 417-424

Köhler, A., Deisemann, H., Lauritzen, B. (1992). Histological and cytochemical indices of toxic injury in the liver of dab Limanda limanda. Mar. Ecol. Prog. Ser. 91: 141-153

Kraupp-Grasl, B., Huber, W., Dutz, B., Gerbracht, U., SchulteHermann, R. (1990). Tumour promotion by the peroxisome proliferator Nafenopin involving a specific sub-type of altered foci in rat liver. Cancer Res. 50: 3701-3708

Lowe, D. M., Moore, M. N., Evans, B. M. (1992). Contaminant impact on interactions of molecular probes with lysosomes in living hepatocytes from dab Limanda limanda. Mar. Ecol. Prog. Ser. 91: 135-140

Lohse, J (1990). Distribution of organochlorine pollutants in North Sea sediments. International Conference on North Sea Pollution - Technical Strategies for Improvement. IAWPRC, EWPCA, NVA, Amsterdam, p. 227-236

Malins, D. C., McCain, B. B., Landahl, J. T., Myers, M. S., Krahn, M. M., Brown, D. W., Chan, S. L., Robal, W. T (1988). Neoplastic and other diseases in fish in relation to toxic chemicals, an overview. Aquat. Toxicol. 11: 43-67

Mix, M. C. (1986). Cancerous diseases in aquatic animals and their association with environmental pollutants: a critical literature review. Mar. environ. Res. 20: 1-141

Moore, M. N. (1990). Lysosomal cytochemistry in marine environmental monitoring. Histochem. J. 22: 187-191

Moore, M. N. (1992a). Pollutant-induced cell injury in flatfish (dab) livers: use of fluorescent molecular probes in live hepatocytes. Mar. environ. Res. 34: 25-31

Moore, M. N. (1992b). Molecular cell pathology of pollutantinduced liver injury in flatfish: use of fluorescent probes. Mar. Ecol. Prog. Ser. 91. 127-133

Moore, M. N., Evans, B. M. (1992). Detection of ras oncoprotein in liver cells of flatfish (dab) from a contaminated site in the North Sea. Mar. environ. Res. 34: 33-38

Moore, M. N., Simpson, M. G. (1992). Molecular and cellular pathology in environmental impact assessment. Aquat. Toxicol. 22: $313-322$

Moore, M. J., Smolowitz, B., Stegmann, J. J. (1989). Cellular alterations preceding neoplasia in Pseudopleuronectes americanus from Boston Harbor. Mar. environ. Res. 28: $425-429$

Murchelano, R. A., Wolke, R. E. (1991). Neoplasms and nonneoplastic liver lesions in winter flounder Pseudo- pleuronectes americanus from Boston Harbour, Massachusetts. Environ. Health Perspect. 90: 17-26

Myers, M. S., Landahl, J. T., Krahn, M. M., Johnson, L. L., McCain, B. B. (1990). Overview of studies on tiver carcinogenesis in English sole from Puget Sound: evidence for a xenobiotic chemical etiology. I: Pathology and epizootiology. Sci. total Environ. 94: 33-50

Myers, M. S., Landahl, J. T., Krahn, M. M., McCain, B. B. (1991). Relationships between hepatic neoplasms and related lesions and exposure to toxic chemicals in marine fish from the US West Coast. Environ. Health Perspect. 90: $7-15$

Pearse, A. G. E. (1968, 1970). Histochemistry theoretical and applied, Vols. 1-2, 2nd edn. Churchill Ltd, London

Renton, K. W. Addison, R. F. (1992). Hepatic microsomal mono-oxygenase activity and P450IA mRNA in North Sea dab Limanda limanda from contaminated sites. Mar. Ecol. Prog. Ser. 91: 65-69

Rhodes, L. D., Myers, M. S., Gronlund, W. D., McCain, B. B. (1987). Epizootic characteristic of hepatic and renal lesions in English sole, Parophrys vetulus, from Puget Sound. J. Fish Biol. 31: 395-407

Rijnsdorp, A. D., Vethaak, A. D., van Leeuwen, P. I. (1992). Population biology of dab Limanda limanda in the southeastern North Sea. Mar. Ecol. Prog. Ser. 91: 19-35

Schulte-Herman, R., Timmerman-Trosiener, I., Barthel, G., Burch, W. (1990). DNA synthesis, apoptosis and phenotypic expression as determinants of growth of altered foci in rat liver during phenobarbitol promotion. Cancer Res. 50: $5127-5135$

Schiewe, M. H., Weber, D. D., Myers, M. S., Jacques, F. J., Reichert, W. L., Krone, C. A., Malins, D. C., McCain, B. B., Chan, S. L., Varanasi, U. (1991). Induction of foci of cellular alteration and other hepatic lesions in English sole exposed to an extract of an urban marine sediment. Can. J. Fish. Aquat. Sci. 48: 1750-1760

Simpson, M. G. (1992). Histopathological studies in the liver of dab (Limanda limanda) from a contamination gradient in the North Sea. Mar. environ. Res. 34: 39-43

Stegeman, J. J., Lech, J. J. (1991). Cytochrome P-450 monooxygenase systems in aquatic species: carcinogen metabolism and biomarkers for carcinogen and pollutant exposure. Environ. Health Perspect. 90: 101-109

Vethaak, A. D. (1992). Gross pathology and histopathology in fish: summary. Mar. Ecol. Prog. Ser. 91: 171-172

Vethaak, A. D., Bucke, D., Lang, T., Wester, P. W. Jol, J., Carr, M. (1992). Fish diseases monitoring along a pollution transect: a case study using dab Limanda limanda in the German Bight. Mar. Ecol. Prog. Ser. 91: 173-192

Varanasi, U., Stein, J E. (1991). Disposition of xenobiotic chemicals and metabolites in marine organisms. Environ. Health Perspect. 90: 93-100

Weisburger, J. H., Williams, G. M. (1991). Critical effective methods to detect genotoxic carcinogens and neoplasm promoting agents. Environ. Heaith Perspect. 90: 121-126 